\title{
Serum neutralization with different types and subtypes of bovine herpesvirus 1 and $5^{1}$
}

\author{
Carine Lidiane Holz ${ }^{2,4}$, Samuel Paulo Cibulski², Thais Fumaco Teixeira ${ }^{2,4}$, \\ Helena Beatriz C.R. Batista ${ }^{3,4}$, Diógenes Dezen ${ }^{2,4}$, Fabrício Souza \\ Campos $^{3,5}$, Ana Paula M. Varela ${ }^{2}$ and Paulo Michel Roehe $e^{2,3^{*}}$
}

\begin{abstract}
Holz C.L., Cibulski S.P., Teixeira T.F., Batista H.B.C.R., Dezen D., Campos F.S., Varela A.P.M. \& Roehe P.M. 2010. Serum neutralization with different types and subtypes of bovine herpesvirus 1 and 5. Pesquisa Veterinária Brasileira 30(7):515-522. Instituto de Pesquisas Veterinárias Desidério Finamor, Fepagro Saúde Animal, Eldorado do Sul, RS 92990-000, Brazil. E-mail: proehe@gmail.com

The serum neutralization (SN) test is the gold standard method to measure neutralizing antibodies to bovine herpesviruses. However, in view of the further subdivisions of bovine herpesviruses in types/subtypes, defining which virus to use at challenge in SN tests may be difficult. In view of that, this study was carried out to re-evaluate (SN) sensitivity with different types/subtypes of bovine herpesviruses types 1 (BoHV-1) and $5(B \circ H V-5)$ as challenge viruses. Bovine sera $(n=810)$ were collected from two distinct geographic regions and tested by SN with three type 1 viruses (BoHV-1.1 strains "Los Angeles" and "EVI123/98"; BoHV-1.2a strain "SV265/96") and three type 5 viruses (BoHV-5a strain "EVI88/95"; BoHV-5b strain "A663" and BoHV-5c "ISO97/95"). SN tests were performed with a 1 hour incubation of the serum-virus mixtures at $37^{\circ} \mathrm{C}$ against 100 TCID50 of each of the viruses. SN sensitivity varied greatly depending on the challenge virus used in the test. The highest sensitivity (327 positive/810 total sera tested; $40.37 \%$ ) was attained when the positive results to the six viruses were added together. No association could be found between any particular type or subtype of virus and the sensitivity of the test. When positive results to each single strain were considered, SN sensitivity varied from $41.7 \%$ to $81.7 \%$, depending on the virus and the geographic region of origin of the sera. Variation was detected even when challenge viruses belonged to the same subtype, where disagreement between positive results reached $41 \%$. These results indicate that one hour incubation $\mathrm{SN}$ tests against single viruses, as performed here, may display a significantly low sensitivity $(p=0.05)$; performing $S N$ tests against a number of different viruses may increase considerably SN sensitivity. Furthermore, the choice of virus used for challenge is critical in $\mathrm{SN}$ tests. In addition, sera from different geographic regions may give rise to disagreeing results with different strains of BoHV-1 and BoHV-5. This might be particularly relevant for control programs and in international trade, were maximum sensitivity should be targeted.
\end{abstract}

INDEX TERMS: Neutralization, cross-neutralization, BoHV-1, BoHV-5.

\footnotetext{
1 Received on May 29, 2009.

Accepted for publication on August 19, 2009.

2 Instituto de Pesquisas Veterinárias Desidério Finamor (IPVDF), Fepagro Saúde Animal, Estrada do Conde 6000, Cx. Postal 47, Eldorado do Sul, RS 92990-000, Brazil. *Corresponding author: proehe@ gmail.com

${ }^{3}$ Laboratório de Virologia, Departamento de Microbiologia (DM), Instituto de Ciências Básicas da Saúde (ICBS), Universidade Federal do Rio Grande do Sul (UFRGS), Av. Sarmento Leite 500, sala 208, Porto Alegre, RS 90050-170, Brazil.

4 Programa de Pós-Graduação em Ciências Veterinárias, Faculdade de Veterinária, Universidade Federal do Rio Grande do Sul(UFRGS), Av. Bento Gonçalves 9090, Porto Alegre, RS 95320-000.

5 Programa de Pós-Graduação em Microbiologia do Meio Ambiente, DM, ICBS, UFRGS, Av. Sarmento Leite 500, Porto Alegre, RS 90050-170.
}

RESUMO.- [Soroneutralização com diferentes tipos e subtipos de herpesvírus bovinos 1e 5.] O teste de soroneutralização (SN) é o método padrão para a mensuração de anticorpos neutralizantes para herpesvírus bovinos. Entretanto, com as subdivisões propostas destes agentes em tipos e subtipos, a definição de qual amostra utilizar como virus de desafio à SN pode ser difícil. Em vista disso, este estudo foi realizado para re-avaliar a sensibilidade de testes de SN utilizando diferentes tipos e subtipos de herpesvírus bovinos tipos 1 (BoHV-1) e 5 (BoHV-5) como amostras de desafio. Soros bovinos $(n=810)$ foram coletados de duas regiões geográficas distintas e testados frente a amostras do tipo 1 (BoHV-1.1: 
amostras "Los Angeles" e "EVI123/98", BoHV-1.2a: amostra "SV265/96") e três amostras do tipo 5 (BoHV-5a: "EVI88/95"; BoHV-5b: "A663" e BoHV-5c "ISO97/95"). Os testes de SN foram realizados com incubação de 1 hora a $37^{\circ} \mathrm{C}$ da mistura soro-vírus, frente a 100 doses infectantes para $50 \%$ dos cultivos celulares $\left(\mathrm{DICC}_{50}\right)$ de cada um dos vírus. A sensibilidade da SN variou grandemente em função do vírus utilizado no teste. A maior sensibilidade (327 soros positivos/810 soros testados; $40.37 \%$ ) foi alcançada quando os resultados positivos frente aos seis diferentes vírus foram somados. Nenhuma associação foi detectada entre determinado tipo/subtipo de vírus e a sensibilidade do teste. Quando resultados positivos frente a cada vírus foram considerados isoladamente, a sensibilidade da SN variou entre $41,7 \%$ a $81,7 \%$, dependendo do vírus de desafio e da região geográfica de origem das amostras de soro. Variação foi detectada mesmo quando as amostras de desafio pertenciam a um mesmo subtipo; a discrepância entre os resultados positivos atingiu até $41 \%$. Estes resultados indicam que testes de $\mathrm{SN}$ contra amostras isoladas de vírus podem apresentar uma sensibilidade notadamente baixa; o emprego de diferentes amostras de vírus de desafio pode aumentar consideravelmente a sensibilidade da prova. Além disso, a escolha da amostra de vírus para a realização do teste é crítica. Outro achado importante é que sorors de diferentes regiões geográficas podem dar resultados discordantes frente a diferentes amostras de BoHV-1 e BoHV-5. Estes achados são particularmente relevantes para programas de controle destas infecções e para o comércio internacional, onde a sensibilidade deve ser maximizada.

TERMOS DE INDEXAÇÃO: Neutralização, neutralização cruzada, BoHV-1, BoHV-5.

\section{INTRODUCTION}

Bovine herpesvirus type 1 (BoHV-1) and type 5 (BoHV-5) belong to the order Herpesvirales, family Herpesviridae, subfamily Alphaherpesvirinae, genus Varicellovirus (Davison et al. 2009). With basis on antigenic and genomic properties, BoHV-1 isolates or have been divided into three different genotypes: BoHV-1.1 and BoHV-1.2a and BoVH-1.2b (Metzler et al. 1985, D'Arce et al. 2002, Souza et al. 2002). Subtypes 1.1 and 1.2a are regarded as most pathogenic and have been associated, respectively, to respiratory disease and abortions (Miller et al. 1991). BoHV$1.2 \mathrm{~b}$ isolates are considered of moderate pathogenicity (Metzler et al. 1985) and may cause vulvovaginitis or balanopostitis, but have not so far been linked to abortions (Miller 1991, Smith et al. 1995). Regarding BoHV-5, these have been further subdivided in BoHV-5a, BoHV-5b and BoHV-5 "non-a, non-b", or "c" (Pidone et al. 1999, D'Arce et al. 2002).

Different BoHV-1 and BoHV-5 types and subtypes display extensive serological cross-reactivity which can be evidenced in serum neutralization tests (Teixeira et al. 1998). This crossreactivity precludes the use of $\mathrm{SN}$ to distinguish type-specific immune responses or to discriminate between infections with viruses of distinct types. However, the actual degree of serologic cross-reactivity induced by such viruses has not been evaluated in detail. Most diagnostic and research laboratories rely on SN tests with a single challenge virus - usually a BoHV-1.1 strain - to evaluate serological responses to bovine herpesviruses (Perrin et al. 1993, 1994, Kramps et al. 1996, Van Oirschot 2000). As both virus types (and most subtypes) may circulate in herds, the choice of a challenge virus may significantly influence the test's sensitivity (defined here as the capacity to detect positive sera within a population of serum samples). To check this hypothesis, in the present study the sensitivity of the SN test was evaluated using BoHV-1 and BoHV-5 strains of different types and subtypes as challenge viruses. The main aim of the study was to determine which virus (or combination of viruses) would give rise to maximum sensitivity. In addition, as most laboratories make use of subtype BoHV-1.1 in SN tests, two strains of this subtype were included in order to determine whether sensitivity might also be affected by strain variation within a subtype.

As additional variation might also arise in function of the geographical region of origin of the sera to be tested, sera from two geographically distant regions were used in the comparative evaluations. The present article reports the findings of such experiments.

\section{MATERIALS AND METHODS}

\section{Cells}

The Madin-Darby Bovine Kidney (MDBK) cell lineage, originally obtained from ATCC (CCL-22), was multiplied in Eagle's minimal essential medium (MEM; Gibco) supplemented with $10 \%$ fetal bovine serum (Soraly, Brazil) and antibiotics (penicillin and streptomycin) at usual concentrations (Paul 1970). All cells, sera and media were tested free of bovine viral diarrhea virus (BVDV), bovine herpesviruses or antibodies to such viruses. Cells were tripsinized every three to four days following standard procedures (Paul 1970).

\section{Viruses}

The following viruses were used: BoHV-1.1 strain Los Angeles ("LA"; Madin et al. 1956), BoHV-1.1 strain EVI123/98 (Roehe et al. 1997, Souza et al. 2002), BoHV-1.2a SV265/96 (Franco et al. 2002), BoHV-5a strain EVI88/95 (Roehe et al. 1997, Souza et al. 2002), BoHV-5b strain A663 (Carrillo et al. 1983, D'Arce et al. 2002) and BoHV-5 "non-a, non-b" (or "BoHV-5c") strain ISO97/95 (Souza et al. 2002). Within the so far known BoHV-1 and BoHV-5 subtypes, only a representative of subtype BoHV-1.2b was not included in the present study, as it was not available in the laboratory. Virus multiplication and titrations were carried out on MDBK cells following standard procedures (Roehe et al. 1997).

\section{Cattle serum samples}

Sera from 810 cattle were examined in the present study; 502 were collected in Southern Brazil, state of Rio Grande do Sul (RS); 308 serum samples were collected from the CentroOeste region, state of Goiás (GO). All sera were obtained from adult cattle with no history of vaccination to bovine herpesviruses. All sera were heat inactivated and stored at $-20^{\circ} \mathrm{C}$.

\section{Neutralization tests}

Neutralizing antibodies to BoHV-1 e BoHV-5 were detected in a serum-virus neutralization test (SN) with the constant virus, varying serum method. SN tests were carried out in 96-well cell culture plates as described previously by Van Oirschot (2000). 
Sera were diluted in twofold dilutions $(1 / 2$ and $1 / 4)$ and the serumvirus mixtures (equal volumes of $50 \mu \mathrm{L}$ ) were incubated at $37^{\circ} \mathrm{C}$ for 1 hour before the addition of MDBK cells ( 3 to $5 \times 10^{4}$ cells/ well/50 $\mathrm{LL})$. Tests were performed separately against each of the six different virus strains, with about 100 fifty per cent tissue culture infectious doses (TCID50) in every case. Plates were incubated at $37^{\circ} \mathrm{C}$ in a moist atmosphere with $5 \% \mathrm{CO} 2$ for up to 120 hours until the final reading, which was performed with basis on the presence or absence of a cytopathic effect. Results were calculated by the method of Reed and Muench (Lorenz \& Bögel 1973) and expressed as positive (neutralizing antibody titre $\geq 2$ or negative neutralizing antibody titre $<2$ ). The sensitivity of the test was here defined as the capacity to detect antibodypositive sera in relation to the maximum number of positive sera detected in samples from either of the two geographic regions or over the total number of positive sera and was calculated with a $95 \%$ confidence interval. Sera which reacted positively at SN with at least one of the viruses were considered positive; sera which reacted negatively with all six viruses were considered negative. All tests were repeated at least twice by different operators. Sera that gave rise to discrepant results (that is, disagreeing results to different $\mathrm{SN}$ challenge viruses) were tested at least three times against the different viruses.

\section{Statistical analysis}

Comparisons of results at $\mathrm{SN}$ tests with different viruses were performed with the McNemar 's test for related populations (Zar 1999) over the total number of sera considered as antibodypositive, with a $5 \%$ significance level and a $5 \%$ probability, calculated with the program Dag Stat (Mackinnon 2000).

\section{RESULTS}

The results of the tests on the 810 bovine serum samples against the six different BoHV strains used as challenge viruses at SN tests are shown on Table 1 . A total of 327 sera ( 163 sera from the state of RS and 164 sera from the state of GO) were considered positive for neutralizing antibodies to at least one of the viruses tested, whereas 483 sera were negative in all tests. The sensitivity of the SN test was strongly affected by the strain used at challenge (Table 1). Maximum sensitivity was achieved by adding positive results obtained at $\mathrm{SN}$ with the six different viruses (327/810 sera; $40.37 \%$ ) (Table 1). Results on Table 1 were expressed considering both "regionalized" positive sera $(n=163$ or 164$)$ and the total number of sera which resulted positive to at least one of the viruses tested $(n=327)$,

The larger the number of viruses considered at SN testing, the higher the sensitivity attained. The test challenge viruses which provided the highest sensitivities varied depending on the combination of viruses considered and the origin of sera (Table 1 and Fig.1).

On serum samples from RS, statistical analysis with the McNemar's test revealed that least number of test challenge viruses to which the cumulative sum of positive results gave rise to a significant level of sensitivity (in this case $99.4 \%$, or $162 / 163$ positive samples) was achieved only when the positive results to four viruses (LA, EVI123, EVI88 and A663) were added (Table 1).

On the other hand, on serum samples from GO, the cumulative sum of positive results to three strains (EVI123, EVI88 and A663) was sufficient to give rise to significantly results at the McNemar's test (that is, sensitivity equal to $97 \%$, or 159/ 164 positive samples detected) (Table 1).

When examining results to single challenge viruses or the cumulative sums of positive results to two viruses, no combination was sensitive enough $(p=0.05)$. The single virus which detected most positive sera when used in SN tests was BoHV-5b strain A663. However, this strain detected only 116/163 (71.2\%) positive sera from Rio Grande do Sul (RS) and 134/164 (81.7\%) positive sera from Goiás (GO) (total $250 / 327 ; 76.4 \%$ of all sera positive with at least one virus). Therefore, if tests with only one of the six viruses were to be considered, the results could give would miss at least $23.6 \%$ of all neutralizing antibody-positive sera.

The second single strain which displayed the highest overall sensitivity was the classical LA strain, which detected about $70 \%$ of the positive sera, as it did on average with all sera tested (Table 1). However, in sera from GO, the virus which displayed the second highest sensitivity was BoHV-5c strain ISO97/95, which detected $129 / 164(78.7 \%)$ positive sera from that state. Interestingly, strain ISO97/95 performed poorly with sera from RS (95/ 163; sensitivity $56.4 \%$ ), what lowered its overall sensitivity (221/327 sera, or $67.6 \%)$.

When comparing the performances of viruses within a same subtype (BoHV-1.1 strains LA and EVI123/98) at SN, LA detected $231(70.6 \%)$ and EVI 123/98 detected 216 (66.1\%) of the total 281 positive sera detected by the two viruses added together (Table 1). This corresponds to an overall sensitivity of $85.9 \%$ over the total number of positive sera detected by the six viruses (281/327). Therefore, the single use of each of these two viruses in $\mathrm{SN}$ tests would give rise to negative results in between $29.4 \%$ and $33.9 \%$ of the tests which resulted positive with at least one of the six viruses tested $(n=327)$. Moreover, within the sera which reacted positively to either of the two BoHV-1.1 strains, agreement on positive reactions was only found in $166 / 281$ sera (59\%); the remainder 115 sera gave rise to discrepant results, depending on which BoHV-1.1 test challenge strain was considered (Fig.1). Thus, it became evident that a large number of sera could give rise to discrepant results, not only with viruses of distinct types and subtypes, but also with viruses within a same subtype (Fig.1). Yet in any of such cases the results would reveal a significantly low sensitivity $(p=0.05)$.

The neutralizing antibody-positive results obtained at SN were sparsely distributed between the different virus strains, in such a way that no pattern could be recognized in the reactivity profiles obtained (Fig.1). In Figure 2 it is shown that sera whose antibodies were recognized by 1, 2, 3, 4, 5 or 6 viruses were quite disperse.

The results were also examined in search for any pattern that could allow differentiation between type-specific neutralizing antibody responses (Fig. 3). However, no such pattern could be detected, in view that most sera were actually recognized by viruses of both types, with only a minor proportion of sera (BoHV-1: 11.6\%; BoHV-5: 10.7\%) displaying type-specific neutralizing antibody response. 
Table 1. Performance (individualized and cumulative) of different bovine herpesvirus strains (BoHV-1 and BoHV-5) as challenge viruses in serum neutralization (SN) tests on sera with neutralizing antibody positive results to at least one of the viruses tested, from two distinct geographical regions of Brazil (Rio Grande do Sul , RS, Goiás, GO)

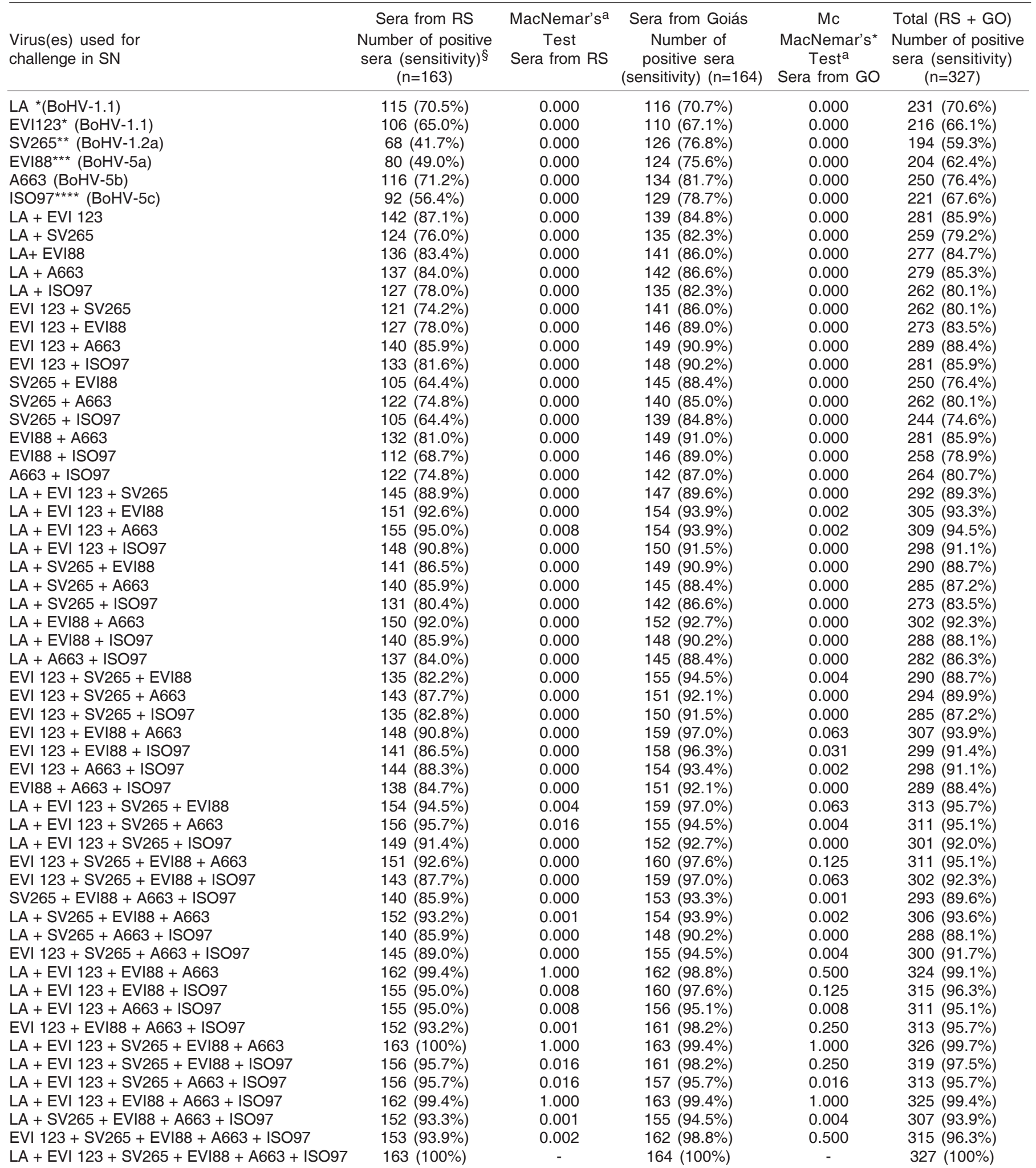

* BoHV-1.1 strains Los Angeles (LA) and EVI123/98; ${ }^{* *}$ BoHV-1.2a strain SV265/96; ***BoHV-5a strain EVI88/95; ${ }^{* \star * *}$ BoHV-5 strain ISO97/95. $\S$ Sensitivity calculated within a $95 \%$ confidence interval, over $n=163$ on sera from RS, on sera from GO: $n=164$; on total positive sera $n=327$.

a Values $\geq 0.05$ are considered significant. 

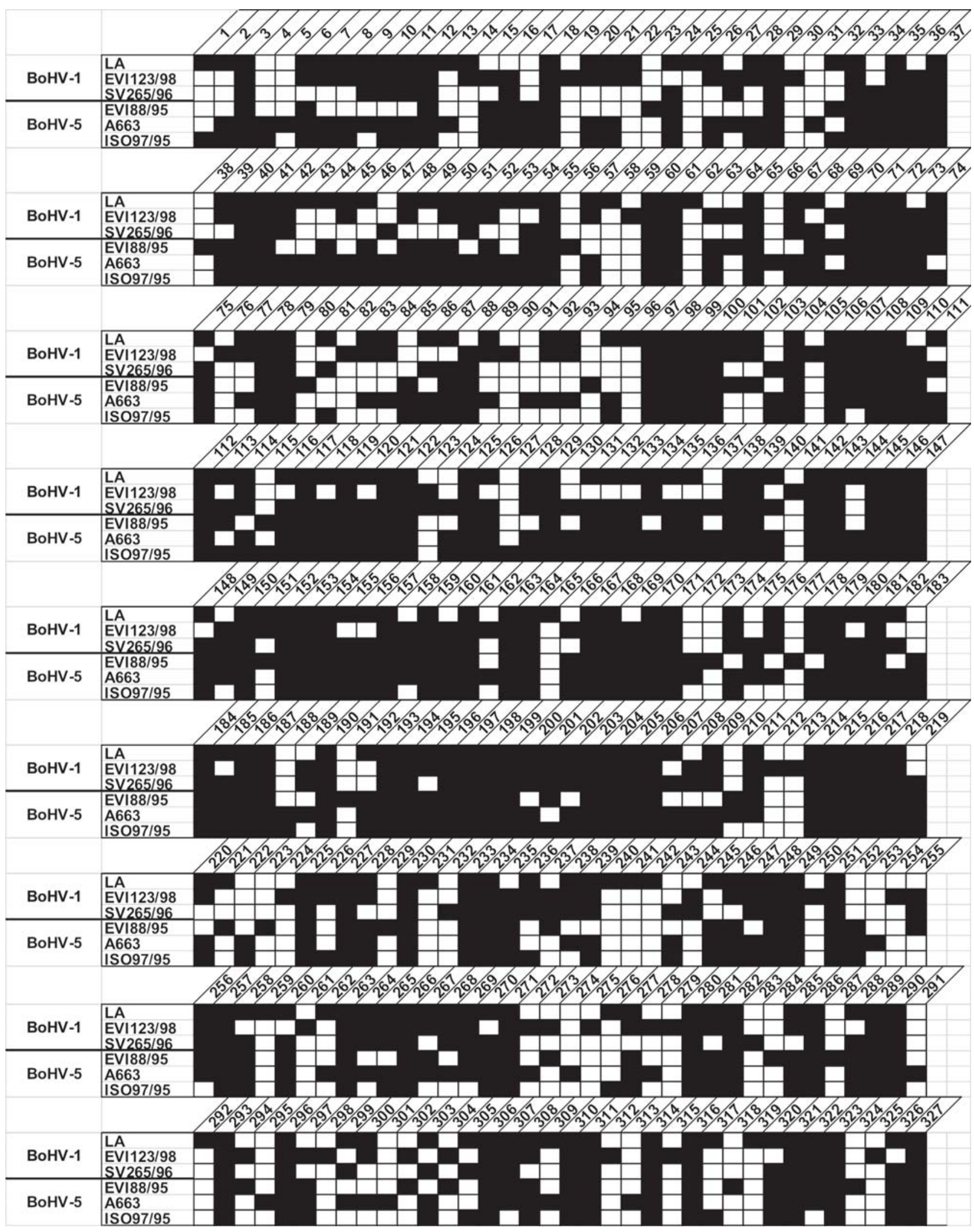

Fig.1. Comparative results of serum neutralization (SN) tests on sera which reacted positively with at least one of the six challenge viruses (BoHV-1: LA, EVI123/98, SV265; BoHV-5: EVI88/95, A663, ISO97/95). Sera numbered sequentially ( 1 to 327$)$. Black squares = positive reaction; white squares = negative reaction. SN tests performed independently with each single challenge virus. 


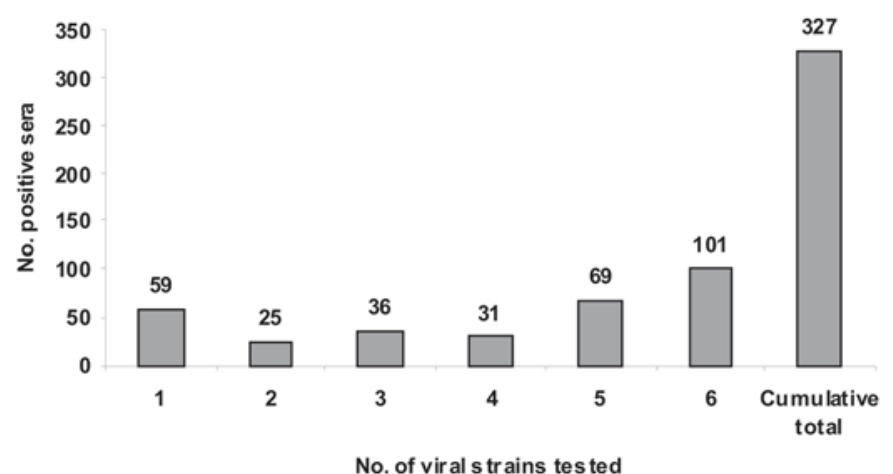

Fig.2. Number of sera positive at serum neutralization (SN) recognized by $1,2,3,4,5$ or 6 bovine herpesvirus strains at challenge (total positive sera $=327$ ).

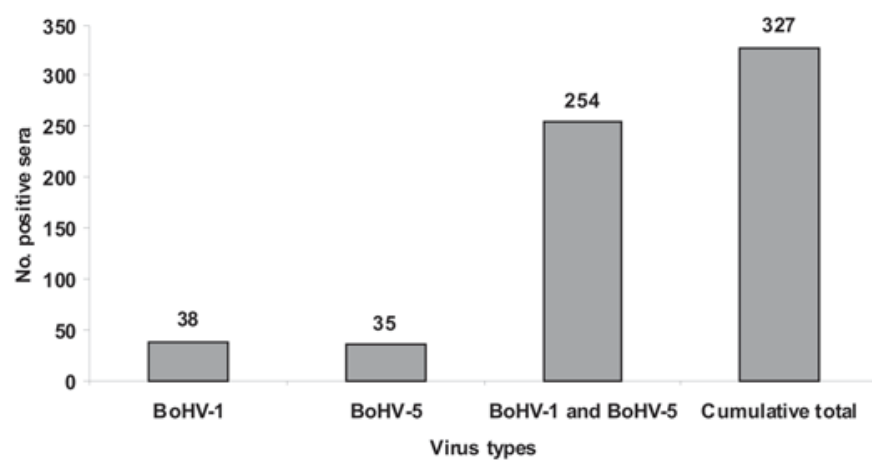

Fig.3. Type specific reactivity. Serum samples which reacted positively in serum neutralization tests against (at least one of) different strains of BoHV-1, BoHV-5, or both.

\section{DISCUSSION}

It became clear in the present studies that the sensitivity of the 1 hour incubation SN test was significantly affected by the BoHV strain used as test challenge virus. When SN tests performed against each individual virus were taken as single results, the lack of sensitivity of the 1 hour SN was striking. These would lead to "false negatives" ranging from $58.3 \%$ of sera from RS with strain SV265/96 to $18.3 \%$ with strain A663, the latter the single most sensitive challenge virus. Yet, even with the most reactive test challenge virus, the number of "false negatives" obtained with such test would be highly significant $(p=0.05)$. These results may be a cause for concern as many diagnostic laboratories perform 1 hour incubation $\mathrm{SN}$ with one test virus, as performed here.

Another point examined here was the role for the geographical area of origin of sera. This variable was examined since possible exposure of a particular cattle population to different viruses might lead to different serological responses. The results obtained here indicate that this was indeed the case. Despite the virus strain that detected sera with the highest sensitivity in sera from both $\mathrm{RS}$ and GO was the same, the differences between findings were striking.

It may be argued that known negative and positive controls were not included in the testing procedure. However, no sera were available that had ever been tested against such a variety of BoHV- 1 and BoHV-5 types/subtypes. Therefore, it is the belief of the authors that the best representatives of antibody-negative serum samples are in fact those tested here that were actually negative to all test challenge viruses. Likewise, truly antibody-positive samples can be considered those that revealed antibodies to at least one of the viruses employed here at challenge.

False positive results may have accounted for some of the discrepant results observed here. Such possibility has also been raised in other studies where SN was examined (Perrin et al. 1993). Likewise, nonspecific crossreactions with other herpesviruses may also have played some role in these findings. As these possibilities were not specifically examined here, these cannot be ruled out. Nevertheless, the authors believe that the high number of test repetitions performed here would have diluted such effects, which would be expected to be rare events, rather than the rule. Therefore, occasional false positive sera or crossreactivity with other herpesviruses would not be expected to invalidate the bulk of findings reported here, although these cannot be completely ruled out and may have played some part in these studies.

No correlation was evident between the results at SN and each particular virus type or subtype tested here. Thus, type/ subtype-specific responses could not be detected with the screening method here employed. It might be expected that neutralizing antibody titrations might reveal differential levels of antibodies - at least to a particular virus type. However, in a previous study, type differentiation could not be achieved by neutralizing antibody titration, since titres would not differ significantly ( $\geq$ four times) in about $92 \%$ of sera (Teixeira et al. 1998). Therefore, it seems that BoHV-1 and BoHV-5 types and more so subtypes - do not induce a discriminative neutralizing antibody response that could be used as a type or subtype-specific marker. In addition, cattle may possibly be infected with more than one virus type/subtype.

Despite the lower sensitivity revealed here, single challenge $\mathrm{SN}$ tests have been used to support eradication programs, such as in Finland (though eventually replaced by ELISA; Nuotio et al. 2007). However, in that country, the number of infected flocks and seropositive animals was low, and the infecting virus was probably of a same origin, making strain variation less likely. In other situations where seroprevalence is expected to be high, as may be the number of circulating viruses, testing for antibodies by SN against a single virus will probably lead to misleading results and put eventual eradication or control strategies at risk.

Low sensitivity can compromise control efforts, what highlights the importance of the findings here reported. Particularly where eradication is to be achieved, and in view of the particularities of herpesvirus latency, false negative results might miss a significant population of potential virus shedders, thus compromising eradication policies and perpetuating the infection in flocks. Moreover, in situations were seronegativity is a mandatory requirement such as in the international trade of animals (Perrin et al. 1993, 1994, Kramps et al. 1996, Van Oirschot 2000), regulatory organs 
should take into account the findings here reported if maximum sensitivity at testing is to be attained.

Another point which is inevitably raised from the analysis of the data presented here regards type-specific prevalence. From above, it is not possible to infer whether BoHV-1, BoHV5 or both virus types are actually prevalent in sampled cattle. Likewise, looking back into the various studies performed on BoHV-1 prevalence performed in Brazil, based solely on testing with a single BoHV-1 at SN challenge (Lovato et al. 1995, Lage et al. 1996, Melo et al. 1997, Cerqueira et al. 2000, Barbosa et al. 2005) it would not be possible to measure the extent of BoHV-5 contamination of such data. So, to date, it is not possible to infer whether those reflect BoHV-1 prevalence, BoHV- 5 prevalence or mixed infections. Perhaps the same might apply for other countries where BoHV-5 may be endemic, or where information on BoHV-5 is missing.

It is quite possible that other, more sensitive tests, such as ELISAs, might prove more adequate in serological studies than SN against single viruses (Collins et al. 1985). Nonetheless, ELISAs for antibodies to bovine herpesviruses should have their validation parameters redefined with sera tested against a wider number of viruses. This might reveal that perhaps many of the discrepancies found between results of SN and ELISAs may in fact be due to SN's low sensitivity, what becomes evident particularly when tests are performed and compared within different laboratories (Perrin et al. 1993, 1994, Kramps et al. 1996). As previously reported, SN with a 24 hour incubation (Bitsch 1978, Perrin et al. 1993) is expected to be more sensitive than the one hour incubation SN. In view of that, a similar study with a 24 hour incubation SN is presently being performed in order to examine the effect of a longer incubation on SN's sensitivity with different bovine herpesvirus types and subtypes (Varela et al. 2010).

Acknowledgements.- To Prof. Lucas Veiga (UFCSPA) for help with the statistical analyses. Financial support from CNPq, FAPERGS, CAPES, and the State Government of Rio Grande do Sul. During this work, CLH was a MSc fellow at the Programa de Pós-graduação em Ciências Veterinárias (PPGCV), Universidade Federal do Rio Grande do Sul (UFRGS); TFT and HBCRB are doctorate fellows of PPGCV/UFRGS. FSC is on receipt of a MSc grant from Programa de Pós-graduação em Microbiologia Agrícola e do Ambiente (PPGMAA), UFRGS. PMR is a CNPq $1 C$ research fellow. We thank Luciana R. Roehe and Martha T. Oliveira for help with the SN and Dr. A.C. Franco for expert advice. Thanks also to Dr. Wilia D. Brito for the serum samples from the state of Goiás.

\section{REFERENCES}

Barbosa A.C.V.C., Brito W.M.E.D. \& Alfaia B.T. 2005. Soroprevalência e fatores de risco para a infecção pelo herpesvírus bovino tipo 1 (BHV-1) no Estado de Goiás, Brasil. Ciência Rural 35(6):1368-1373.

Bitsch V. 1978. The $\mathrm{P}^{24-37}$ modification of the infectious bovine rhinotracheitis virus-serum neutralization test. Acta Vet. Scand. 19:497505.

Carrillo B.J., Ambrogi A., Schudel A.A., Vazquez M., Dahme E. \& Pospichil A. 1983. Meningoencephalitis caused by IBR virus in calves in Argentina. Zentralbl. Veterinärmed. B 30:327-332.

Cerqueira R.B., Carminati R., Silva J.M., Soares G.C., Meyer R. \& Sardi S. 2000. Serological survey for bovine herpesvirus 1 in cattle from different regions in the state of Bahia, Brazil. Braz. J. Vet. Res. Anim. Sci. 37(6):497-500.
Collins J.K., Bulla G.A., Riegel C.A. \& Butcher A.C. 1985. A single dilution enzyme-linked immunosorbent assay for the quantitative detection of antibodies to bovine herpesvirus type 1. Vet. Microbiol. 10(2):133-147.

Davison A.J., Eberle R., Ehlers B., Hayward G.S., McGeoch D.J., Minson A.C., Pellett P.E., Roizman B., Studdert M.J. \& Thiry E. 2009. The order Herpesvirales. Arch. Virol. 154:171-177.

D'Arce R.C.F., Almeida R.S., Silva T.C., Franco A.C., Spilki F.R., Roehe P.M. \& Arns C.W. 2002. Restriction endonuclease and monoclonal antibody analysis of Brazilian isolates of bovine herpesviruses types 1 and 5. Vet. Microbiol. 88(4):315-324.

Franco A.C., Rijsewijk F., Flores E.F., Weiblein R. \& Roehe P.M. 2002. Construction and characterization of a glycoprotein $E$ deletion mutant of bovine herpesvirus type 1.2 strain isolated in Brazil. Braz. J. Microbiol. 33:274-278.

Kramps J.A., Perrin B., Edwards S. \& Van Oirschot J.T. 1996. A European inter-laboratory trial to evaluate the reliability of serological diagnosis of bovine herpesvirus 1 infections. Vet. Microbiol. 53:153161.

Lage A.P., Castro R.S., Melo M.I.V., Aguiar P.H.P., Filho J.B.B. \& Leite R.C. 1996. Prevalence of antibodies to bluetongue, bovine herpesvirus 1 and bovine viral diarrhea/mucosal disease viruses in water buffaloes in Minas Gerais State, Brazil. Rev. d’Elev. Méd. Vét. Pays Tropic. 49(3):195-197.

Lorenz R.J. \& Bögel K. 1973. Methods of calculation, p.329-332. In: Kaplan M.M. \& Koprowsky H. (Eds), Laboratory Tecniques in Rabies. World Health Organization, Geneva.

Lovato L.T., Weiblen R., Tobias F.L. \& Moraes M.P. 1995. Herpesvírus bovino tipo 1 (HVB-1): inquérito soro-epidemiológico no rebanho leiteiro do estado do Rio Grande do Sul, Brasil. Ciência Rural 25(3):425-430.

Mackinnon A. 2000. A spreadsheet for the calculation of comprehensive statistics for the assessment of diagnostic tests and inter-rater agreement. Comput. Biol. Med. 30(3):127-134.

Madin S.H., York C.J. \& McKercher D.G. 1956. Isolation of the infectious bovine rhinotracheitis virus. Science 129(1):721-722.

Melo C.B., Oliveira A.M., Figueiredo H.C.P., Leite R.C. \& Lobato Z.I.P. 1997. Prevalência de anticorpos contra Herpesvírus bovino-1, vírus da diarréia viral bovina e vírus da leucose enzoótica bovina em bovinos do Estado de Sergipe, Brasil. Revta Bras. Reprod. Anim. 21(2):160-161.

Metzler A.E., Matile H., Gassmann U., Engels M. \& Wyler R. 1985. European isolates of bovine herpesvirus 1: a comparison of restriction endonuclease sites. polypeptides. and reactivity with monoclonal antibodies. Arch. Virol. 85:57-69.

Miller J.M. 1991. The effects of IBR virus infections on reprodutive function of cattle. Vet. Med. 86(1):790-794.

Miller J.M., Whetstone C.A. \& Van der Maaten M.J. 1991. Abortifacient property of bovine herpesvirus type 1 isolates that represent three subtypes determined by restriction endonuclease analysis of viral DNA. Am. J. Vet. Res. 52:458-461.

Nuotio L., Neuvonen E. \& Hyytiäinen M. 2007. Epidemiology and eradication of infectious bovine rhinotracheitis/infectious pustular vulvovaginitis (IBR/IPV) virus in Finland. Acta Vet. Scand. 49(1):3.

Paul J. 1970. Cell and Tissue Cultures. $4^{\text {th }}$ ed. E. and S., Livingstone, London.

Perrin B., Bitsch V., Cordioli P., Eliot M., Guérin B., Lenihan P., Rønsholt I., Van Oirschot J.T., Vanopdenbosch E., Wellemans G., Wizigmann G. \& Thibier M. 1993. A European comparative of serological methods for the diagnosis of infectious bovine rhinotracheitis. Rev. Sci. Tech. Off. Int. Epiz. 12:964-984.

Perri B., Calvo T., Cordioli P., Coudert M., Edwards S., Eliot M., Guérin B., Kramps J.A., Lenihan P., Paschaleri E., Perrin M., Schon J., Van Oirschot J.T., Vanopdenbosch E., Wellemans G., Wizigmann G. \& Thibier M. 1994. Selection of European Union standard reference 
sera for use in the serological diagnosis of infectious bovine rhinotracheitis. Rev. Sci. Tech. Off. Int. Epiz. 13:947-960.

Pidone C.L., Galosi C.M., Etcheverrigaray M.E., Nosetto E.O. \& Etcheverrigaray M.E. 1999. Restriction endonuclease analysis of BHV1 and BHV-5 strains isolated in Argentina. J. Vet. Med. B 46(7):453-456.

Roehe P.M., Silva T.C., Nardi N.B., Oliveira L.G. \& Rosa J.C.A. 1997. Diferenciação entre os vírus da rinotraqueíte infecciosa bovina (BHV1) e vírus da encefalite bovina (BHV-5) com anticorpos monoclonais. Pesq. Vet. Bras. 17(1):41-44.

Smith G.A., Young P.L. \& Reed K.C. 1995. Emergence of a new bovine herpesvirus 1 strain in Australian feedlots. Arch.Virol. 140:599-603.

Souza V.F., Melo S.V., Esteves P.A., Schmidt C.S., Gonçalves D.A., Schaefer R., Silva T.C., Almeida R.S., Vicentini F., Franco A.C., Oliveira E.A., Spilki F.R., Weiblein R., Flores E.F., Lemos R.A., Alfieri A.A., Pituco E.M. \& Roehe P.M. 2002. Caracterização de herpesví- rus bovinos tipos 1 (BHV-1) e 5 (BHV-5) com anticorpos monoclonais. Pesq. Vet. Bras. 22(1):13-18.

Teixeira M.F.B., Esteves P.A., Coelho C.S.S., Silva T.C., Oliveira L.G. \& Roehe P.M. 1998. Diferenças em níveis de anticorpos neutralizantes contra herpesvírus bovinos tipos 1 (BHV-1) e 5 (BHV-5). Pesq. Agrop. Gaúcha 4(1):61-65.

Van Oirschot J.T. 2000. OIE Manual of Standards for Diagnostic Tests and Vaccines. $4^{\text {th }}$ ed. Office International des Epizooties, Geneve, Switzerland, p.381-391.

Varela A.P.M., Holz C.L., Cibulski S.P., Teixeira T.F., Antunes D.A., Franco A.C., Dezen D., Cenci A. \& Roehe P.M. 2010. Neutralizing antibodies to different subtypes of bovine herpesvirus type 1 (BoHV1) and 5 (BoHV-5). Vet. Microbiol. 142:254-260.

Zar J.H. 1999. Biostatistical Analysis. $4^{\text {th }}$ ed. Prentice Hall, New Jersey, p.169-175. 